\title{
РЕЖИСЕРСЬКІ ІННОВАЦІЇ У ВИКОРИСТАННІ ТЕХНІЧНИХ ЗАСОБІВ I ТЕХНОЛОГІЙ У СЦЕНІЧНОМУ МИСТЕЦТВІ
}

\author{
Катерина Юдова-Романова ${ }^{1 a}$, Вікторія Стрельчук²a, Юлія Чубукова ${ }^{3 b}$ \\ ${ }^{1}$ кандидат мистецтвознавства, доцент; e-mail: iudovakateryna@gmail.com; ORCID: 0000-0003-2665-390X \\ ${ }^{2}$ кандидат педагогічних наук, професор; e-mail: maximile@ukr.net; ORCID: 0000-0002-8516-5829 \\ ${ }^{3}$ магістр; e-mail: julia.pazieieva@gmail.com; ORCID: 0000-0002-9217-9372 \\ а Київський національний університет культури і мистецтв, Київ, Україна \\ b TOB «CU Ajans», освітньо-розважальна і шоу-мейкерська компанія, Анталія, Туреччина
}

\begin{abstract}
Анотація
Мета дослідження полягає у виявленні й аналізі режисерських інновацій використання технічних засобів і технологій у сценічних постановках як нових, так і традиційних форм. Для досягнення поставленої мети використано наступні методи: теоретичний підхід - для вивчення наукової літератури; аналітичний та компаративний - для визначення впливу технологічної складової на режисуру сучасних творів сценічного мистецтва; системний - для проведення структуризації нових жанрів сценічного мистецтва, поява яких зумовлена запровадженням сучасних технічних засобів, інженерних та інформаційних технологій; прогностичний - для визначення нових тенденцій у режисурі творів сценічного мистецтва. Наукова новизна полягає у мистецтвознавчому аналізі модернізації сценічного простору та вивченні ролі інноваційних технічних засобів і технологій у режисурі сучасних творів сценічного мистецтва. Висновки. У XXI ст. еволюція театралізованих масових видовищ відбувається під впливом активного розвитку технологій та пошуку нових способів інтерактивності. Характерною рисою сучасних режисерських рішень $€$ синтез літературної, музичної, хореографічної, сценографічної складових, що втілюються на різноманітних сценічних майданчиках, модернізація яких помітна як щодо використовуваних матеріалів, функціональності, мобільності, так і щодо впровадження новітніх інформаційних комп'ютерних та інженерних технологій. Мультимедійний підхід став одним з провідних творчо-технологічних методів створення сучасного театралізованого видовища. Поширення імерсійних театрів і запровадження методів тифлокоментування доводять, що режисери сучасності використовують технології абсолютно різнобічно, а творчі пошуки форми дозволяють сучасною мовою втілювати надзавдання. Мобільність, візуальність, яскравість, новаторство, спрямованість до кожного з глядачів за активної участі останніх у дійстві - основні напрями творчих пошуків режисерів.
\end{abstract}

Ключові слова: сценічне мистецтво; технологічні засоби; режисерські інновації; мультимедійні технології; інтерактивність

\section{Постановка проблеми}

Стрімкий розвиток і поширення нових інформаційних і телекомунікаційних технологій набуває сьогодні характеру глобальної інформаційної революції, що призводить до зростання впливу на політику, економіку, управління, науку, культуру 
та інші сфери життєдіяльності суспільства в межах національних кордонів та у світі загалом. Інформаційні технології, новітні технічні можливості, розвиток і вдосконалення як побутових, так і спеціалізованих пристроїв позначилися у цілому на соціокультурній ситуації, не залишаючи поза впливом і мистецтво, зокрема сценічне.

В епоху інформаційних технологій методи впливу на глядача постійно піддаються модернізації. Сценічне мистецтво не стоїть осторонь глобальних цивілізаційних процесів - щоб залишатися популярним воно має бути видовищним, інноваційним, що, зокрема, часто досягається через широке креативне застосування в постановках останніх новинок в індустрії сценічних технічних засобів та їхніх технологій.

Мета дослідження - виявити та проаналізувати режисерські інновації використання технічних засобів і технологій у сценічних постановках як нових, так і традиційних форм.

\section{Аналіз останніх досліджень і публікацій}

В. В. Базанов (2005), В. Й. Берьозкін $(2011,2016 a, 2016 b)$ вивчають питання теорії та історії сценографії загалом. Нові технології у сучасному художньопостановочному процесі розглядає Т. В. Астаф'єва (2011). І. Е. Горюнова (2009) вивчає значення використання комп'ютерної графіки та піротехнічних засобів для режисури. І. В. Ескузович (2004) фокусує свої дослідження на акустиці та звуковому забезпеченні сценічних майданчиків. Л. М. Михайлов (2007) сферою своїх досліджень обрав технічні засоби оформлення сучасного естрадного видовища. К. В. Юдова-Романова комплексно в теоретично-історичному та практичному ключі звертається до вивчення різних аспектів технічного забезпечення оформлення сценічного простору (2017a), зокрема ароматичного (2016), піротехнічного (2018), пневматичного (2017b) та ін. Г.К.Липківська діагностує та систематизує стан мультимедійних технологій на вітчизняній і закордонній театральній сцені XXI ст. (2018). М.В.Крипчук у своїх дослідженнях аналізує сценічний простір сучасних театралізованих святкових масових видовищ просто неба, а також особливості, принципи та засоби їхнього художнього оформлення в контексті співтворчості художника з режисером (2018, с.229-233).

Аналіз літератури з обраної тематики свідчить про відсутність у дослідженнях вивчення проблем, пов'язаних 3 інноваційними процесами у використанні технічних засобів і технологій режисерами-постановниками нових і традиційних форм сценічного мистецтва.

\section{Виклад основного матеріалу}

Сучасне сценічне мистецтво стрімко розвивається, у ньому широко представлені різні види та жанри: як традиційні, приміром опера, так і нові, що зумовлено саме науково-технічним прогресом. Маємо на увазі появу вистав, шоу, концертів і цілих жанрів, які неможливі без використання технічних засобів. Їх коротко можна структурувати таким чином: 
Вісник Київського національного університету культури і мистецтв.

Серія: Сценічне мистецтво

1) мультимедійні масові заходи, вистави, концерти та церемонії відкриття;

2) інтерактивні спектаклі, імерсійний театр;

3) лазерні та піротехнічні спектаклі;

4) шоу вокалоїдів, голографічне проектування;

5) фемботи, що співають, та інша робототехніка;

6) VR-тури в естрадне шоу та VR-театри.

В усіх цих різновидах та жанрах сценічного мистецтва можуть використовуватися об'ємні декорації, відеопроекції, голографічне проектування, 3D-проектування та інші засоби художньої виразності. Нові технології змінюють сценічне мистецтво. У цій статті з метою виявлення та систематизації режисерських інновацій у творах сценічного мистецтва ми проаналізуємо поданий вище перелік шляхом вивчення зібраних первинних даних із сучасної вітчизняної та закордонної сценічної практики. Спробуємо зрозуміти, що за інновації їх реалізують, яким саме чином режисери використовують технології, які зміни відбуваються завдяки технічним засобам у сценічному мистецтві, і чому сучасні технології відкривають нові горизонти для вирішення надзавдань мистецтва.

1. Мультимедійність.

Такі технічні засоби, як світлотехніка, засоби звукового, візуального оформлення - світлодіодні екрани високої якості, сценічно-модульні конструкції, генератори ефектів, піротехніка, аеростати, стали не прикрасою чи акцентом, а нормою та необхідною умовою професійного сучасного сценічного мистецтва. Якісне поєднання всього вищеперерахованого створює мультимедійність, тобто різноманіття форм спілкування, а у випадку, що ми розглянули,- різноманіття технічних засобів виразності, поєднаних на сцені. Постановки різних форм сценічного мистецтва на сьогодні є мультимедійними. Тут потрібні зусилля цілої спільноти фахівців, у тому числі звукорежисерів, відеорежисерів, режисерів зі світла, фахівців зі спецефектів, з комп'ютерних технологій та ін. Їх роль значна. Через неправильно відрегульований мікрофон, несфокусований світловий прилад, неправильно встановлений піротехнічний пристрій або збій в програмному забезпеченні комп'ютера можуть звестися нанівець усі зусилля режисерів і виконавців. Неприпустимі також дефекти у фонограмі - вони можуть зіпсувати ідеальну сценографію та чудовий сценарій. Тому від творців мультимедійного продукту вимагають фахових знань у багатьох сферах мистецької діяльності, що передбачає професійне використання музики, тексту, пластики, кінематографа, телебачення, графічного зображення, а також оволодіння знаннями з програмування та монтажу. Усе це в комплексі має сприяти втіленню художньої ідеї в яскравій та видовищній формі. Мультимедійність як синтезуючий комплексний прийом у поданні художніх образів має утримувати увагу, впливати на емоції й уяву сучасного вибагливого глядача. Варто зазначити, що високий рівень технічного устаткування - це необхідна сучасному сценічному мистецтву умова існування, але зовсім недостатня. Кожен мультимедійний проект прагне стати інноваційним, але не кожен таким $є$.

Розглянемо яскравий приклад поєднання модерного сценічного простору з оперною музикою та глибокою драматургією, що створює єдине ціле, 
мультимедійне дійство. Мова йде про оперний фестиваль, який відбувається щоліта в липні-серпні, в невеликому місті Брегенц, Австрія. Істрія фестивалю бере початок у далекому післявоєнному 1946 році. Тоді все дійство проходило на двох баржах: на палубі однієї грав оркестр, іншої - йшла вистава. Сьогодні як і тоді особливістю, головною родзинкою музичного фестивалю є сцена на Боденському озері, яку зведено просто неба, безпосередньо на поверхні-водойми, хоча відтоді під водою з'явився залізобетонний підмурок для встановлення декорацій. Розміри сценічного майданчика, фантазійні декорації, простір зоряного неба та темні води озера створюють неповторну, вражаючу атмосферу (Bregenzer Fest Spiele, 2019; AUSTRO-RUS, 2016).

3 першого ж року фестиваль набув статусу міжнародного, оскільки участь у ньому взяли представники Німеччини, Швейцарії та Франції. Постійним й одним з головних учасників $є$ Віденський симфонічний оркестр, що виступає на окремому майданчику, а також бере участь в інших комплексних заходах. Загалом у рамках фестивалю свої роботи показують представники різних музичних і театральних колективів на ангажементних засадах. Свої постановки в різних жанрах здійснюють найкращі світові режисери та художники.

До головного сценічного майданчика - сцени просто неба на Боденському озері - з берега примикає амфітеатр на 7000 місць. На цьому майданчику проходять масштабні вистави музичних жанрів, включно з операми, балетами, рокоперами та мультижанровими спектаклями за класичними творами. Різнопланові заходи відбуваються також на інших локаціях: так званому «Фестивальному театрі» - майданчику для показу рідко виконуваних класичних оперних постановок і концертів; «Майстерні» - майданчику для сучасних театральних опер; «Театрі на зерновому ринку» - майданчику для оперет і драматичних вистав; театрі «Космос» - майданчику для драматичних вистав і крос-культурних вистав.

Додають видовищності декорації-трансформери, які видозмінюються протягом сценічної дії та іноді стають німими персонажами постановок. Наприклад, у 1999 році вистава Дж. Верді «Бал-маскарад» відбулася на гігантській розгорнутій книзі, яку «читав» скелет. У 2017 році режисером вистави став датчанин Каспер Хольтен, який поставив класичну оперу «Кармен» Жоржа Бізе у сучасній інтерпретації. Планшетом сцени тут слугували величезні гральні карти, що розташовувалися на різних рівнях та «авансценою» спускалися у воду. Під класичну музику Ж. Бізе танцівники виконували контемпорарі (EVRONEWS, 2017).

У спектаклі використовувалася найновіша світлотехніка, а технологія відеопроектування створювала ілюзію перегортання гральних карт та зміни мастей. Найбільш яскраві сюжетні колізії підсилювалися піротехнічними ефектами римськими свічками та бураками. Зауважимо, що у закритому архітектурносценічному просторі використання останніх неможливе, адже висота бурака сягає 100 м, що належить до четвертого з п'яти класів небезпеки піротехнічних виробів.

Варто також відмітити розмір виконавців на сценах фестивалю, що складає від 1 до 5\% загальної величини конструкції сцени. Це важливий момент не лише для сприйняття глядача, а й у контексті розгляду інноваційності режисури постановок. Упродовж століть оперний виконавець був основним 
героєм, головною зіркою дійства, на якому в умовах сцени-коробки постійно фокусувалась увага глядачів. У Брегенці він стає творцем драматургії тільки в поєднанні з комп'ютеризованою рухомою сценографією, романтичним пейзажем австрійського міста, світлом, відео- та аудіодизайном і піротехнікою. Відгуки історій Єлизаветинської епохи прослідковуємо через мультимедійність сучасності. Отож, фантастичний театр на воді змінює традиційні акценти художньої образності в оперному мистецтві.

Ще одним з яскравих прикладів мультимедійного видовища $є$ концерти естрадних виконавців та церемонії відкриття, де поєднують театр, музику, танець, унікальну сценографію. Наприклад, церемонія відкриття XXIX Олімпіади в Пекіні 2008 року на національному стадіоні «Пташине гніздо». Тут присутнє поєднання складного аудіовізуального синтезу з драматургією нового типу. Режисером-постановником є відомий китайський кінорежисер Чжан Імоу. За його шоу спостерігали понад 4 млрд. телеглядачів з усього світу.

Початок програми символізували три вісімки - Олімпійські ігри 2008 було офіційно відкрито 8 числа, 8 місяця о 8 годині вечора. У Китаї вісімку вважають щасливим числом. Оркестр з 2008 музикантів гучним ударом гонга сповістив про початок театралізованої вистави. Церемонія складалася з двох частин «Видатна цивілізація» та «Славна ера». У центрі арени було розгорнуто сувій, що важив 800 кг. Він метафорично втілював найважливіший китайський винахід папір. Потім глядачі побачили сцени, що символізували будівництво Великої китайської стіни, винахід друкарства, компаса, порцеляни. Дійство містило також номери, присвячені китайській опері, живопису, писемності, винайденню в Китаї y VIII ст. пороху, вперше використаного для феєрверка. Унікальний візуальний ряд був забезпечений комп'ютерною графікою, мультиплікацією і 3D-проекціями. Спеціальні ефекти органічно поєднувалися з рухами сотень тіл спортсменів, що створювали різні сценічні композиції.

Тенденції до пошуку режисерських інновацій з використанням технічних засобів і технологій прослідковуємо й у творчості українських митців. Непересічною подією для України стало шоу «Барон Мюнхгаузен» (творці визначили жанр як «хореографічне 3D-шоу», постановка К. I. Томільченка (2010р.) за мотивами п'єси Г. І. Горіна «Той самий Мюнхгаузен». «Барон Мюнхгаузен» - перша масштабна вистава в Україні. «Декораційне оформлення практично повністю побудоване на використанні проекційних технологій. Завдяки сучасним матеріалам та технологіям авторам вдалося створити фантастичне середовище, котре захоплює, заворожує, шокує. Стилізація елементів готики, архітектури вікторіанської доби, реалістичних та абсолютно фантастичних пейзажів, відтворених у декораціях на сцені та в 3D-технологіях на спеціальних екранах перетворює все дійство у єдину гармонійну структуру, актори та оточення здаються єдиним цілим. І проекції, і реальні декорації спільно формують сценічне середовище, предмети на передньому плані додають ірраціональності, фантасмагорії видовищу - вони руйнують загальноприйняті й звичні співвідношення масштабів та величин, формують зворотну перспективу», захоплено свідчить С. Т. Триколенко (2013). 
Високопрофесійним мультимедійним шоу у вітчизняному мистецькому світі $\epsilon$ театралізований хореографічний спектакль «Вартові мрій» (2015, режисер К. І. Томільченко), який вміщає об'ємні декорації, відеопроекції, вбудований батут, портали для артистів, поворотне коло. Кожен з номерів вистави був філігранно вплетений у драматургію вистави.

У відомому естрадному спектаклі «Дім таємничих пригод» К. І. Томільченка (м. Київ, 2017) дуже широко використано відеопроектування. Місяць, який використовують як символ у спектаклі, протягом дії вистави трансформується та видозмінюється - на його тлі з'являються дійові персонажі спектаклю. «Дім таємничих пригод» - це мультижанрове мультимедійне шоу. У ньому поєднано різноманіття режисерських прийомів донесення образної інформації: в акторському виконанні - естрадний спів, циркові та акробатичні номери, воркаут, мюзикл, мініатюру, ілюзіон; технічному - світлове оформлення, сценічний дощ, важкий дим, «зіркове небо» на заднику, об'ємні декорації, поворотне коло, відеопроекцію, світлодіодні екрани, вогняні гармати, 3D-меппінг.

2. Інтерактивні спектаклі

Збільшення асортименту аудіовізуальної масової продукції призвело до зміни взаємин між творчим продуктом і глядачем. Нові технології відкрили перед споживачами аудіовізуального масового продукту нові комунікативні можливості. Взаємодія глядачів і виконавців (так званий інтерактив) є традиційною складовою мистецтва естради. Ще з витоків сценічного мистецтва використовують принцип імпровізаційної взаємодії виконавців і глядачів у театрально-видовищних постановках. Але сьогодні інтерактивність, залишаючись важливою складовою засобів художньої виразності театрально-видовищних постановок, набуває нових форм.

Прикладом використання технічних засобів як форми втілення «діалогу» з глядачем може слугувати відоме «Сніжне шоу» В. І. Полуніна. Звукопідсилювальні прилади в процесі глядацької інтерактивності створюють звуко-шумову партитуру в режимі реального часу. У виставі композитор і звукорежисер Р. Дубінніков не використовує заздалегідь записану фонограму, а всі звукові ефекти та музичні фрагменти імпровізовано створюються за участю глядачів під час спектаклю.

Інтерактивність як режисерський прийом має місце й у виставах імерсійного театру. Імерсійні театри (від лат. immersio - занурюю) характеризуються виходом за межі сценічного майданчика актора і сьогодні користуються у світі все більшою популярністю. Їх також називають театр-променад. Хоча це не зовсім узгоджено з етимологією та суттю - імерсійний театр може існувати не на сценічному майданчику а, наприклад, у ліфті, на заводі, в автобусі. Його особливість полягає в тому, що глядач - не пасивний, а повноправний учасник того, що відбувається.

Ці нові для вітчизняного глядача театри успішно співіснують зі стаціонарними театрами у всьому світі вже більше 20 років. Розглянемо деякі з них.

Наприклад, дія імерсійного театру Sleep No More (PunchDrunk) відбувається в закинутому п'ятиповерховому готелі. Сто кімнат, у кожній з яких розігрується дійство, і тільки людина у венеціанській масці, яку на вході видають глядачеві, 
Вісник Київського національного університету культури і мистецтв.

Серія: Сценічне мистецтво

вибирає, в яку з них зайти. Тут можна підглянути, як хтось кохається, прочитати чиїсь листи, поїсти цукерок у магазині солодощів або приєднатися до театралізованих танців (Brantley, 2011).

Iмерсійний спектакль Remote X (м. Москва), поставлений і зіграний вже в більш ніж 19 містах світу (Бангалор, Відень, Нью-Йорк, Лісабон, Авіньйон, СанктПетербург), поєднує в собі елементи вистави, екскурсії, комп'ютерної гри та квесту. Збираючись на спектакль-променад, глядач стає учасником, він навіть «надягає костюм», адже зручне взуття та одяг можна розглядати не лише як "дрес-код" для глядачів, а як театральний костюм. Група з 50-ти чоловік під керівництвом комп'ютерного голосу в навушниках досліджує власну поведінку у звичному метушливому людському потоці. Глядачам пропонують замислитися над тим, яку роль у житті сучасної людини відіграють новітні технології. Подорожі, дослідження міста у форматі стерео є доволі цікавими (Зинцов, 2015).

Інший приклад з сучасної практики імерсійних театрів - вистава «на колесах» Cargo театру Rimini Protokol. Cargo - це ім'я головного героя, який запрошує глядачів провести з ним дві години «на колесах». Головний герой $є$ далекобійником, а його фура - центральне і єдине місце дії цієї історії. Глядачі в машині, Cargo - за кермом. Пересувний театр. Маємо приклад сучасного втілення, повернення до театральних витоків (Зинцов, 2017).

Вистава «Нереальні впливи» театру «Театр.dос» (м. Москва) - це філософський спектакль-променад, в якому немає чіткого сценарію. Початково відомі лише зав'язка події та відправна точка маршруту. Дійство, що відбувається далі, залежить від головного героя (за сумісництвом режисера вистави Всеволода Лісовського), його комунікації з глядачем та дій професійних акторів. Тільки від глядача актори дізнаються, яким маршрутом підуть далі, які текстові фрагменти, пластичні імпровізації та в якій послідовності виконуватимуть. Занедбані будинки, громадські туалети, торгові центри, приватні квартири та вулиці перетворюють глядача на ведучого такого перфомансу (Лисовский, 2016).

Український приклад імерсійного театру - спектакль-променад «Час» від компанії U! Zahvati режисерки П. Бараніченко. Минулого року національна компанія U! Zahvati впровадила для глядача-інтелектуала новий для нашої країни жанр. Виставапроменад, в анотації до якої написано «виводимо глядача із затяжної культурної коми», привернула до себе увагу навіть людей, абсолютно далеких від театру.

Зібравшись на Пішохідному мості, група з 35 осіб одягає навушники. Слухаючи гіда, вони починають маршрут. Пересуваються Києвом, де кожна будівля, вітрина, лавка завдяки аудіозапису трансформується зі звичних архітектурних форм у красномовну декорацію (https://uzahvati.com.ua/).

3. Лазерні та піротехнічні спектаклі.

Еволюція кольоро- світломузики відбувається відповідно розвитку нових мультимедійних технологій. Синтез музичного, світлового та піротехнічного контенту дозволяє інженерам створювати нові форми для митців. Нові видовища з'являються шляхом поєднання складних просторово-графічних світлових проекцій, комп'ютеризації та музики. Результатом еволюції стала поява лазерних шоу, піротехнічних спектаклів, водних й електронних феєрій. Піромузичні шоу - це 
Bulletin of Kyiv National University of Culture and Arts

Series in Stage Art

спектаклі-феєрверки, в яких піротехнічні ефекти накладаються на музичний твір, тобто феєрверк слідує за музичними підйомами та спадами, за настроєм музики. Такий феєрверк попередньо моделюють на комп'ютері за допомогою програмного забезпечення, створюють комп'ютерний сценарій, який вже відпрацьовують безпосередньо на майданчику феєрверк-шоу. Приклад вітчизняної піромузичної вистави - «Концерт вогню», що відбувся 28 квітня 2011 р. у Києві на Співочому полі в Печерському ландшафтному парку. Глядачі розміщувалися просто неба амфітеатром навколо сцени, сидячи на лавах та пагорбах зеленого театру. У виставі органічно в єдиному ритмі поєднувалися музика барабанів і приголомшливі піротехнічні ефекти - різного виду феєрверки та відкритий вогонь. На небесному екрані ночі музиканти-піротехніки створювали дивовижні фігури, спіралі та лінії, тимчасом як їх потужні та гучні барабани відбивали й прискорювали ритм (Юдова-Романова, 2018).

Ще один приклад піротехнічного спектаклю реалізовується на різних поверхнях і $є$ також мультимедійним. Вистава «Ромео і Джульєтта» в постановці режисера Ксенії Сафі з Москви - це новий, сучасний погляд на класику У. Шекспіра. Автори цього мистецького твору визначають жанр вистави таким чином: «балет-вистава і фаєр-шоу». Цей інноваційний проект розпочинається просто неба із настанням темряви. Режисер демонструє історію кохання через мультижанрову творчість, що поєднує в собі балет, фаєр-шоу, піротехніку та повітряну акробатику. Відбувається спектакль біля фронтальної частини фортеці Сетунь, що додає автентичності, достовірності епохи відтворюваного дійства (Другой город, 2016).

Усе більшої популярності набувають театралізовані видовища, де основним візуальним компонентом $є$ спеціальні світлові, лазерні та піротехнічні ефекти з комп'ютерною графікою. Наразі розглянемо режисерські новації використання лазерних технологій. Лазерне шоу - спектакль, головним елементом якого є лазерна система. Такий різновид шоу може прикрасити й емоційно підвищити зорове сприйняття масового театралізованого видовища, концертної програми або бути самостійним інструментом розповіді історії. Перше публічне шоу з використанням лазера відбулося 9 травня 1969 року в Окланді, штат Каліфорнія. Саме там і тоді Л. Кросс, К. Джеффріс і Д. Тюдор показали невелике шоу з використанням криптонового лазера. Ця ідея виникла, коли Л. Кросс і К. Джеффріс хотіли додати візуальний компонент до електронної музики. Упродовж семи років вони ретельно працювали, i 1976 року на промислову основу було поставлено виробництво лазерних проекторів InterScan. Метою компанії була розробка та виготовлення лазерних систем для реклами, розваг, освіти, медицини тощо. Підготовка та показ компанією лазерного шоу в той час коштували \$3,000 на тиждень (ЮдоваРоманова, 2017, с.208-209).

4 лютого 1977 в Бостонському планетарії InterScan показала перше лазерне шоу в трьох частинах з оригінальним сюжетом і музичним супроводом. До середини березня таке видовище відвідали більше 15 тис. осіб. Квиток коштував \$3, і шоу окупило себе за тиждень у 10 разів. Із цього моменту й почався бурхливий розвиток лазерних технологій у сфері розважальної культури, естради й театру. Вітчизняний глядач вперше зіткнувся з лазером як елементом сценографії на 
концерті французької групи Sрасе (тоді мала назву Paris France Transit), що проходив у 1983 році під час туру групи по СРСР в СК «Олімпійський». Лазер був закріплений на головному уборі лідера групи Д. Маруані.

Варто відзначити, що важливим елементом лазерного шоу є музичний супровід. Якісна синхронізація музики живої чи електронної та лазерних ефектів емоційно впливає на глядачів і формує гармонійний творчий альянс.

4. Шоу вокалоїдів та голографічне проектування.

3D-технології впевнено увійшли в сценічне мистецтво та завоювали любов глядачів, акторів і постановників. Створення віртуального простору на сцені й у залі відкриває невичерпні можливості для фантазії і творчих експериментів. Завдяки моделюванню та встановленим інфрачервоним датчикам на порожній сцені можна створити тривимірну композицію вулиці мегаполісу, середньовічного замку, військових баталій і не тільки.

На європейській церемонії вручення нагороди MTV Awards 2005 року в Ліссабоні відбувся виступ британської віртуальної групи «Горіллаз» (Gorillaz). Програму Musion Eyeliner System (дослівно «Система музичної підводки для очей») використали для створення тривимірних голографічних мультперсонажів Gorillaz, які виступають на сцені, тобто фактично з'являються на екрані, що перекриває дзеркало сцени. Зазвичай учасники популярного у світі британського «віртуального гурту» під час живих концертів виступали у вигляді силуетів на гігантському екрані в поєднанні із зображеннями своїх мультиплікаційних alter ego (Musion Holograms, 2007).

Проривом 2010 року можна вважати «вихід на сцену» вокалоїда Хатсуне Міку в реальних концертних залах - коли в супроводі живих музикантів у ролі солістки співає тривимірна анімована героїня. Ця абсолютно нова форма виступу на сьогодні $є$ частиною концертної естради. Хатсуне $є$ надзвичайно популярною в Японії, її прихильники створили цілу субкультуру, і жоден тематичний японський фестиваль не обходиться без косплеєрів артистки. Один із кліпів Хатсуне набрав понад три з половиною мільйони онлайн-переглядів.

«Ми намагаємося ще більше розвивати технологію та зробити синтезатор мови якнайближчим до людського голосу, - каже Хіроюкі Іто, керівник Crypton Future Media з Японії, що створив Хатсуне. - Ми плануємо перевершити людський голос і створити те, що ще не існує. Сподіваюся, ця нова технологія створить новий вид музики» (YouTube, 2016).

За 13 років з моменту появи голографічні технології на сьогодні досягли такого розвитку, що зробити живий концерт з Міку Хатсуне в Японії тепер не проблема навіть для дітей. 8 січня 2018 року в музичному коледжі Senzoku Gakuen, у місті Кавасакі (між Токіо та Йокогама), відбувся студентський симфонічний концерт за участю Міку Хатсуне, що був курсовою студентською роботою на тему музичного та звукового дизайну. Усі виконавці й організатори заходу були студентами коледжу. Вхід на концерт безкоштовний. Студенти займалися світловим оформленням та озвучуванням. Крім того, на сцені з'явилася сама співачка на напівпрозорому екрані. Зображення виводилося за допомогою проектора (як на другому концерті Міку Хатсуне, версія якої - Miku FES'09 31 серпня 2009 року, зараз використовують 
безекранну технологію голографічного проектування). Анімацію рухів вокалоїда так само робили студенти.

У 2018 році відбулося кругосвітнє турне цієї виконавиці. Концертні виступи Хатсуне проходили на найбільших стадіонах Японії, кількість глядачів на одному з яких сягала п'ятдесяти тисяч осіб. А загалом аудиторія виконавиці налічує не один десяток мільйонів прихильників у всьому світі.

За допомогою голограми в сценічному мистецтві можуть не лише створювати нових виконавців. Як відомо, Елвіс Преслі помер у 1977 році, але його образ повернувся до глядачів у вигляді цифрової тривимірної голограми. Тривимірна віртуальна копія «короля рок-н-ролу» виконує головні ролі в різних постановках і шоу. Для створення голограми Елвіса Преслі використано технологію, яка полягає в обробці фахівцями-аніматорами всіх відеозаписів співака, складанні на їх основі найдокладнішої тривимірної моделі людини, визначивши послідовність рухів, які він здійснював, виступаючи на сцені. У технології використовують генерацію зображення за допомогою комп'ютерної графіки.

У такий спосіб «оживали» Уітні Хьюстон, Майкл Джексон, Тупак Шакур. Технології та режисерські інновації дають можливість поєднувати голограму та «живий» хореографічний балет. На хвилі гучних повернень у 2014 році на сцені вручення музичної премії Billboard Music Awards з'явився король поп-музики. У межах випуску другого посмертного альбома Майкла Джексона його голографічний образ заспівав пісню Slave to the Rhytm з музичної збірки Xscape, яку за життя співак не виконував. Проекція була досить яскравою та якісною, а перформанс доповнила попередньо відзнята та вбудована в проекцію група танцівників. Це дало змогу голографічному Майклу Джексону рухатися поміж живих фігур на сцені, на яких також розповсюджувалася проекція, підсилюючи ефект. Було відтворено всі відомі рухи короля поп-музики, включно з «місячною ходою» (Gallo, 2014).

5. Фемботи, що співають, та інша робототехніка.

Фембот (від англ. famale - жінка та robot) або дівчина-робот - улюблений додаток японських робототехніків. Найбільших успіхів на сьогодні у створенні таких рободівчат досяг Національний інститут прогресивної промислової науки і технології (AIST). У 2009 році він представив модель HRP-4C, яка могла здійснювати прості рухи та співати, супроводжуючи спів мімікою (при цьому використовували вокальний синтезатор Yamaha). У 2010 році вдосконалена дівчина-робот змогла не тільки співати, але й танцювати на сцені в супроводі танцівниць.

Навчити робота танцювати завдання вельми нетривіальне. I хоча кліп, де танцює дівчина-робот, не містить особливих хореографічних складнощів, але програмування навіть таких танцювальних рухів досі було вкрай трудомістким завданням. Тепер же творці HRP-4C не тільки домоглися чудового сценічного ефекту, а й значно спростили життя майбутніх «імпресаріо» роботів-танцюристів.

Якщо на сцені танцюють кілька людей в однаковому одязі, то людське око може не розрізняти окремих танцівників. Можливо, тому кліп, де танцює дівчинаробот, є досить моторошним через схожість з виступами звичайних «дівочих груп». Ймовірно, це стало причиною незатребуваності у сценічному мистецтві технологій фемботів (LiveJournal, 2010). 
Вісник Київського національного університету культури і мистецтв.

Серія: Сценічне мистецтво

За останні 10 років робототехніка розвивалася дуже активно, і режисерипостановники сценічних дійств не трималися осторонь цього процесу. Однією з останніх тенденцій в еволюції сценічного дизайну стала поява масової робототехніки. Так, прикладом демонстрації «творчості» роботів був виступ на Центральному телебаченні Китаю CCTV з нагоди настання Китайського Нового 2016 року співака Сун Нана в супроводі роботів і дронів, які виконували синхронний танець. Понад 700 мільйонів людей подивилися трансляцію масштабного шоу на китайському телебаченні, згодом до них долучилися й інтернет-користувачі з усього світу. Під час телешоу Spring Festival Gala 540 роботів синхронно танцювали під святкову пісню. При цьому 29 безпілотників з різнокольоровим підсвічуванням, планеруючи в такт музиці, розсипали з повітря метафан над танцполом з танцюристами-роботами. Політ дронів ніби наочно ілюстрував текст пісні «Китай злітає на вершину світу». Як видно у телеверсії, жоден робот не порушив загальної синхронної картини виступу (Юдова-Романова, 2017, с.224).

У сфері театрально-видовищної діяльності сучасні моделі квадрокоптерів надають постановникам унікальні можливості для дизайну сценічного простору. Несучи на собі різні освітлювальні прилади, маючи фактично необмежені можливості щодо траєкторії руху та синхронізації з іншими складовими мультимедійних шоу, дрони сміливо входять у режисуру та дизайн сценічного простору. Це унікальний засіб сценічного дизайну та привабливий спосіб донести в художній формі інформацію до будь-якої за обсягами аудиторії.

Світлове шоу квадрокоптерів - технологічна альтернатива феєрверкам. Використання дронів безпечніше й етичніше. Вони не спричинять пожежі та не розбудять дітей у сусідніх кварталах. Містяни будуть вдячні режисерам.

Під час шоу в небо піднімаються квадрокоптери розміром з тарілку. Завдяки яскравому підсвічуванню їх видно здалеку. Використовуючи рій з десятків дронів, можна вибудовувати в повітрі статичні та рухомі фігури (Левандовский, 2018).

Провести шоу доречно з будь-якої нагоди - від ювілею компанії до відкриття Олімпійських ігор. У лютому 2018 понад 1200 дронів виробництва компанії Intel Shooting Star засяяли в небі над Пхенчханом під час церемонії відкриття зимових Олімпійських ігор. Дрони були обладнані масивом кольорових світлодіодів. Вони спочатку ефектно об'єднались у фігуру сноубордиста, а потім в нічному небі запалали олімпійські кільця (Юдова-Романова, 2018, с.240-243).

Використання дронів можливе в абсолютно різних масштабах. Наприклад, художнє вирішення постановки дефіле Dolce \& Gabbana в межах Міланського тижня моди - 45 хвилин на подіумі моделей замінили безпілотники, які під музику виносили із-за лаштунків модні сумочки.

6. VR-тури в естрадному шоу та VR-театри

До режисерських інновацій використання новітніх технічних засобів у сценічному мистецтві зараховуємо також технології віртуальної реальності або альтернативної реальності VR та AR. Технологія VR (англ. Virtual reality - віртуальна реальність) дозволяє занурити людину в штучно сконструйований світ. Надягаючи навушники, спеціальні окуляри або шолом віртуальної реальності, глядачі опиняються 
в альтернативному всесвіті. Одягаючи окуляри на VR-виставах необхідно крутити головою на всі боки, адже ця технологія охоплює кут $360^{\circ}$. Окуляри створюють відчуття повної ілюзії реальності, перешкоджають сприймати дійсність. Якщо взяти за базис, що сценічне мистецтво прагне репрезентувати альтернативну реальність, іншу від тої, що існує в цей момент, чи місце дії, що існує в іншій точці простору, то VR пропонує, висловлюючись сучасною мовою, зручний інтерфейс для вирішення такого завдання.

На наш погляд, дві тенденції визначать виникнення нової естетики віртуального театру. Перша - це повноцінна інтерактивність, друга - автономність.

Сценічні шоу із застосуванням VR-окулярів захопливо сприймають на Каннському фестивалі, Московському міжнародному кінофестивалі та Венеціанському бієнале. Діє Бельгійський інноваційний VR-театр CREW, у 2017 році відбулася прем'єра вистави «У пошуках автора» в м. Тюмень, де розвивається проект \#VRTheatre. Нова у сценічному мистецтві технологія VR стала полем для експериментів режисерів, сценографів і програмістів з візуальними образами і створенням для глядача ілюзії перенесення всередину реальності вистави.

Нова у сценічному мистецтві технологія VR $€$ результатом експерименту з візуальними образами та розробкою технічних спецефектів для перенесення глядача всередину реальності вистави, $€$ темою, над якою працює творча команда режисерів, сценографів і програмістів.

Маємо такий досвід і в Україні. StarLight Entertainment представляє VR-тур зі спектаклем «Вартові Мрій». Подія була приурочена до 20-річчя компанії «Київстар». У межах VR-туру спеціально обладнаний автобус їздив містами нашої держави, відвідати його міг за бажанням кожен. Показ VR-шоу «Вартові Мрій» здійснювали за підтримки партнера з інновацій Samsung Electronics Україна. У 7-хвилинному панорамному відео $\left(360^{\circ}\right) €$ змога ближче познайомитись із сюжетом популярної зимової казки за допомогою технології віртуальної реальності. Представлений у «Вартових Мрій» мікс жанрів є само собою одним з прикладів сучасних інноваційних тенденцій, описаних вище, а крім того, автори проекту додали ще «другий шар інновацій» у цю виставу. Безкоштовний вхід на VR-шоу «Вартові Mрій» здійснювався в порядку живої черги, що може свідчити про поступове зменшення вартості технології, і дає змогу прогнозувати її подальший розвиток у сценічному (або вже у візуально-віртуальному) мистецтві. Загалом з організаційного погляду VR-тур шоу «Вартові мрій» можна розглядати як рекламну акцію до виходу його повної версії (такий собі дивертисмент технологій XXI століття) (StarLight Entertainment, 2018).

Характерною рисою модернізації сценічного простору y VR-шоу через запровадження технологій віртуальної реальності стала фактична руйнація та зникнення власне сценічного простору.

Зовсім інша річ з технологією доповненої реальності - AR (англ. Augmented reality), яку часто плутають з віртуальною. Тут реальному світу нікуди діватися. У нього вбудовують цифрові предмети, які видно на екрані смартфона. Через додаток в гаджеті глядач може побачити оновлену сцену й героїв, пояснення до сюжету, опис та історичні замальовки до вистави. Звичайний смартфон стає 
Вісник Київського національного університету культури і мистецтв.

Серія: Сценічне мистецтво

аналогом VR-окулярів, які переносять людину в іншу реальність. Такі інновації це нові засоби для поєднання живого дійства, відео та комп'ютерних технологій у реальному часі. Згадана вище бельгійська компанія CREW експерементує у сфері імерсійного театру та змішаної реальності (mixed-reality); була першою, що поєднала технологію $360^{\circ}$ Omni Directional Video (ODV) and Head-mounted display (HMD) для створення альтернативної реальності.

2000-го року CREW створили перформативне, автоматизоване віртуальне середовище Cave. Натхненником проекту став робітник сцени Пол Антипов (Paul Antipoff), який був повністю паралізований внаслідок нещасного випадку. Симбіоз з технологіями зробив можливим його самостійне функціонування в реальності. В імерсії Cave Пол Антипов міг малювати та взаємодіяти з віртуальним актором і глядачами. Досвід, що пропонує CREW, гібридний. Він відрізняється від звичних віртуальних імерсій, що базуються на стабільній позиції глядача, тим, що спостерігач переживає віртуальну реальність через власне тіло, рухається, ходить, біжить. Таке ігрове співвідношення реального часу та записаного матеріалу перетворює глядача в справжнього протагоніста проекту.

CREW неодноразово презентували свої унікальні розробки з використанням гібридних мистецьких форм в найрізноманітніших просторах: на фестивалях перформативного мистецтва, візуального мистецтва, великих масових заходах і наукових конференціях. Цей колектив об'їздив майже всі континенти, зокрема Європу, Китай, Канаду та США (Мистецький Арсенал, 2018).

Митці (режисери-постановники, сценаристи, сценографи), використовуючи новітні технології, прагнуть для свого глядача нового розуміння театрального інтерактиву. I мова сьогодні вже йде не лише про те, що можуть запропонувати віртуальні технології сценічному мистецтву, а й про те, що перформативна практика змінює індустрію нових технологій.

Донедавна це здавалося нереальним, але нові технології дали можливість відкрити світ мистецтва для людей з вадами зору та незрячих. Підключившись до мережі Wi-Fi під час вистави, глядач отримує доступ до тифлокоментарів на своєму гаджеті, голосових коментарів і пояснень.

Тифлокоментування (ТКН, аудіоопис (audio description), аудіодискрипція) (Roofthooft, Remael and Van den Dries, 2018, p.232-248) - це лаконічний описпояснення предмета, простору або дії, які незрозумілі сліпому або слабозорому без спеціальних словесних пояснень, й у формі голосового супроводу, наживо, через технічні пристрої подається реципієнту. Уперше ТКН було здійснено через запис на платівці в СРСР (Москві) 1978 року. Процес виникнення та формування ТКН відбувався майже одночасно й паралельно як на Заході, так і в Радянському Союзі аж до епохи Перебудови. Оскільки ці процеси не перетиналися, з'явилися два терміни на позначення цієї діяльності: ТКН - в СРСР, і аудіодискрипція - на Заході (Демчук, 2014).

Сьогодні ж голоси акторів, задіяних у постановці, лаконічно розповідають про те, що відбувається на сцені, які декорації, міміка та вбрання акторів, що вони роблять, через смартфони (Globustheatre, 2018). Технологія тепер доступна дітям з особливими потребами. Практику ТКН має Казанський Татарський державний 
театр юного глядача імені Г. Карієва. Його директор Мансур Ярміїв зазначив: «Наша сцена має бути доступною для всіх. Вистави з тифлокоментарями дарують можливість людям з особливими потребами зануритися в чарівний світ театру. Це означає, що вони разом з героями постановок одночасно з іншими глядачами зможуть радіти і переживати, сміятися і плакати» (Искусство, наука и спорт, 2018). Прем'єрним спектаклем стала «Дивовижна подорож кролика Едварда» Кейта ДіКамілло.

Київський національний академічний театр оперети став першим у Києві театром, який реалізував постановки вистав із тифлокоментуванням. Узимку 2018 року 33 дитини відвідали три різноманітні вистави з аудіодискрипцією. Для адаптації до незвичних умов діти, а дехто з них прийшов до театру вперше, перед виставою мали можливість ознайомитися з деяким реквізитом. У цей час аудіодискриптор розповідав про персонажів вистави, про майбутню дію (Київський національний академічний театр оперети, 2018). Після вдалого експерименту театр взявся до постановки дитячої лялькової вистави «АндерСон» (режисер Максим Козолуп, 2018) у межах проекту «Арт-дія-інклюзія» (Антоненко, 2018). Ідея театру щодо створення вистав для незрячої аудиторії зародилася під час навчально-практичного семінару на тему «Аудіодискрипція візуальних творів для осіб з порушеннями зору», що проходив у вересні 2017, у Києві (Національна спілка театральних діячів України, 2017).

Наукова новизна дослідження полягає у мистецтвознавчому аналізі процесів модернізації сценічного простору та вивченні ролі інноваційних технічних засобів і технологій у режисурі сучасних творів сценічного мистецтва.

\section{Висновки}

У XXI ст. еволюція театралізованих масових видовищ відбувається під впливом активного розвитку технологій та пошуку нових способів інтерактивності. Характерною рисою сучасних режисерських рішень є синтез літературної, музичної, хореографічної, сценографічної складових, що втілюються на різноманітних сценічних майданчиках, модернізація яких помітна як щодо використовуваних матеріалів, функціональності, мобільності, так і щодо впровадження новітніх інформаційних комп'ютерних технологій. Мобільність, візуальність, яскравість, новаторство, спрямованість до кожного з глядачів, активна участь останніх у дійстві - ось основні напрями творчих пошуків режисерів.

Зокрема, має місце широке застосування комп'ютерної графіки, мультимедійних технологій, «голографічних технологій», 3D-проектування; впровадження мобільних технологій з метою створення атмосфери імерсії, інтерактивних форм, VR-технологій тощо, що стали трендовими елементами в сценічних постановках сьогоднішнього дня.

Феномен мультимедіа став одним з основних творчо-технологічних методів створення сучасного театралізованого видовища. Використання анімації та проекції, сценічних ефектів як в реальному часі, так і в записі, комп'ютерних технологій та роботів свідчить про глибокий синтез нових технологій і мистецтва. 
Результатом пошуків митців є створення нових естрадних жанрів, нових типів театру, абсолютно унікальних за своїм характером і типологічно різноманітних. Можемо стверджувати, що більшість художньо-постановочних нововведень пов'язані з технічним прогресом, не можливі без комп'ютерних технологій та інженерії. Але імерсійні театри та запровадження методики тифлокоментування доводять, що режисери сучасності використовують технології абсолютно різнобічно. Мета творчих пошуків форми - сучасною, актуальною мовою втілювати надзавдання.

Нові медіа дозволили візуалізувати сміливі перформанси, перетворити постановки у повноцінні мультимедійні проекти, де гармонійно поєднуються театр, музика, танець і експромт.

М. Г. Чернишевський у «Нотатках про журнали» 1856 року писав: «Художність полягає у відповідності форми та ідеї... Якщо ідея фальшива, то про художність не може і йти мова, тому що форма буде так само фальшива і повна невідповідностей. Тільки твір, в якому втілена справжня ідея, буває художнім, якщо форма абсолютно відповідає ідеї» (1981). У цій статті ми розглянули використання різних форм сучасних і традиційних видів сценічних мистецтв та побачили, що режисери сучасності намагаються поставити у відповідність форму та ідею, використовуючи останні технічні та інформаційні технології.

Зроблені висновки свідчать, що питання режисерських інновацій у використанні технічних засобів і технологій у сценічному мистецтві є досить широким й охоплює значні процеси, що сьогодні набувають особливої вагомості, а це визначає подальший поглиблений науковий пошук.

\section{СПИСОК ПОСИЛАНЬ}

Антоненко, А., 2018. 16 жовтня у Києві відбудеться прем'єра «АндерСон» у рамках проекту «Арт-дія-інклюзія». День Kiev.ua, [online] 12 жовтня. Доступно: <https://m.day.kyiv.ua/uk/ article/kultura/sluhayemo-vystavy> [Дата звернення 13 березня 2019].

Астафьева, Т.В., 2011. Новые технологии в современном постановочном процессе (на материале театрального искусства Санкт-Петербурга). Кандидат наук. СанктПетербургский гуманитарный университет профсоюзов.

Базанов, В.В., 2005. Технология сцены. Москва: Импульс-свет.

Березкин, В.И., 2011. От истоков до середины XX века. В: Искусство сценографии мирового театра. Москва: УРСС. Т. 1.

Березкин, В.И., 2016. Вторая половина XX века. В зеркале Пражских Квадриеннале 1967-1999 годов. В: Искусство сценографии мирового театра. Москва: Едиториал УРCC. T. 2.

Березкин, В.И., 2016. Мастера XVI-XX вв. В: Искусство сценографии мирового театра. Москва: Едиториал УРСС. Т. 3.

Горюнова, И.Э., 2009. Режиссура массовых театрализованных зрелищ и музыкальных представлений. Санкт-Петербург: Композитор, с.38-43

Демчук, А.Б., 2014. Відеоконтент для незрячих: метод тифлокоментування. Радіоелектроніка, інформатика, управління, [online] 1, с.146-149. Доступно: <http://nbuv. gov.ua/UJRN/riu_2014_1_23> [Дата звернення 20 лютого 2019].

Другой город, 2016. Огненно-пиротехнический балет-спектакль «Ромео и Джульетта». [online] Доступно: <http://www. anothercity.ru/fire-show-new> [Дата обращения 20 февраля 2019]. 
Зинцов, О., 2017. Стартовал театральный проект Cargo Moscow группы Rimini Protokoll. Ведомости, [online] 14 июля. Доступно: <https://www.vedomosti.ru/lifestyle/ articles/2017/07/14/723610-cargo-moscow> [Дата обращения 13 марта 2019].

Зинцов, О., 2015. Стартовал театральный проект Remote Moscow. Ведомости, [online] 31 мая. Доступно: <https://www.vedomosti.ru/lifestyle/articles/2015/06/01/594485startoval-teatralnii-proekt-remote-moscow> [Дата обращения 13 марта 2019].

Искусство, наука и спорт, 2018. Спектакль с тифлокомментированием на татарском языке впервые в Казани. [online] Доступно: <http://artscienceandsport.com/news/ specialview_kazan_tiflo> [Дата обращения 25 февраля 2019]

Київський національний академічний театр оперети, 2018. Проект «Арт-дія-інклюзія» в Національній опереті України. [online] Доступно: <http://operetta.com.ua/proekt-art-diyainklyuziya-v-natsionalnij-opereti-ukrayini/> [Дата звернення 13 березня 2019].

Крипчук, М.В., 2018. Сценічний простір просто неба як складова сучасного театралізованого видовища. Вісник Національної академії керівних кадрів культури $i$ мистецтв, [online] 2, с.229-233. Доступно: <http://nbuv.gov.ua/UJRN/vdakkkm_2018_2_50> [Дата звернення 11 грудня 2018].

Левандовский, А., 2018. Хабр. Шоу дронов: как мы координировали рой танцующих коптеров. [online] Доступно: <https://habr.com/ru/company/croc/blog/427353/> [Дата звернення 20 лютого 2019].

Липківська, Г.К., 2018. Мультимедійні засоби на сучасній театральній сцені. Вісник Київського національного університету культури і мистецтв. Серія: Сценічне мистецтво, 1, с.103-126.

Лисовский, В., 2016. Неявные воздействия Театр. DOC. [online] Доступно: <http://teatrdoc. ru/events.php?id=172> [Дата звернення 20 лютого 2019].

Мистецький Арсенал, 2018. Бельгійський інноваційний VR-театр CREW. [online] Доступно: <https://artarsenal.in.ua/uk/laboratory/proekt/belgijskyj-innovatsijnyj-vr-teatr-crew/> [Дата звернення 20 лютого 2019].

Михайлов, Л.Н., 2007. Создание современного эстрадного зрелища (принципы художественного оформления). Кандидат искусствоведения Российская академия театрального искусства. Москва.

Національна спілка театральних діячів України, 2017. Робимо театр доступним для всіх! [online] Доступно: <https://nstdu.com.ua/publication/ceminar-z-audiodiskriptsiyidopomoga-lyudyam-z-vadami-zoru-pobachiti-vistavu/> [Дата звернення 13 березня 2019].

Триколенко, С.Т., 2013. Використання мультимедійних технологій для оформлення сучасних хореографічних постановок на прикладі шоу-балету «Барон Мюнхгаузен». «Проблеми розвитку сучасного хореографічного мистецтва та шляхи їх вирішення»: матеріали III Всеукраїнської науково-практичної конференції. Луганськ, 5-6 грудня 2013 р. Луганськ: Луганська державна академія культури і мистецтв, с. 106-109.

Чернышевский, Н.Г., 1981. Заметки о журналах. Июнь, июль 1856. (О разборе Н.Ф. Павловым комедии В.А. Соллогуба «Чиновник»). Литературная критика. Москва: Художественная литература. [online] T. 1. Доступно: <http://az.lib.ru/c/chernyshewskij_n_g/ text_0400.shtml> [Дата обращения 20 февраля 2019].

Экскузович, И.В., 2004. Об акустике в театре Макса Рейнхардта. Сцена, 5, с.35

Юдова-Романова, К.В, 2016. Ольфакторна синестезія в сценічному мистецтві. Науковий вісник Київського національного університету театру, кіно і телебачення імені І. К. КарпенкаКарого, 19, с.29-36.

Юдова-Романова, К.В., 2017. Пневматичні засоби конструювання сценічного простору. Вісник Національної академії керівних кадрів культури і мистецтв, 4, с.242-247.

Юдова-Романова, К.В., 2017. Технічні засоби оформлення сценічного простору. Київ : Видавничий центр КНУКіМ. 
Юдова-Романова, К.В., 2018. Дизайн сценічного простору вогняними засобами конструювання. Вісник Національної академії керівних кадрів культури і мистецтв, 1, с. 228-232.

Юдова-Романова, К.В., 2018. Дрони як складова інноваційного сценічного дизайну. Економіка і культура України в світових глобалізацій них процесах: позиціонування і реалії: тези доповідей III Міжнародної науково-практичної конференції, Київ, 21-22 березня 2018. Київ: Видавничий центр КНУКіМ, с. 240-243.

AUSTRO-RUS, 2016. Музыкальный фестиваль в Брегенце. [online] Доступно: <https:// austro-rus.ru/articles/166407> [Дата звернення 13 березня 2019].

Brantley, B., 2011. Shakespeare Slept Here, Albeit Fitfully. The New York Times, [online] 13 April. Доступно: <https://www.nytimes.com/2011/04/14/theater/reviews/sleep-nomore-is-a-macbeth-in-a-hotel-eview.html?adxnnl=1\&ref=theater\&adxnnlx=1309466383d3DY6sXMRulipZI8XWee5Q> [Дата звернення 13 березня 2019].

Bregenzer Fest Spiele, 2019. [online] Доступно: <https://bregenzerfestspiele.com/en\#> [Дата звернення 13 березня 2019]

EVRONEWS, 2017. На фрестивале в Брегенце покажут «Кармен». [online] Доступно: <https:// ru.euronews.com/2017/07/19/bregez-festival-carmen> [Дата звернення 13 березня 2019].

Gallo, Ph., 2014. Michael Jackson Hologram Rocks Billboard Music Awards: Watch \& Go Behind the Scenes. Billbord. [online] Доступно: <https://www.billboard.com/articles/events/ bbma-2014/6092040/michael-jackson-hologram-billboard-music-awards> [Дата звернення 13 березня 2019].

Globustheatre, 2018. Спектакль «Дядюшкин сон» (версия с тифлокомментарием и субтитрами) / театр «Глобус». [online] Доступно: <https://youtu.be/msbOIBnNKQ4> [Дата обращения 20 февраля 2019].

LiveJournal, 2010. Выступление девушки-робота на сцене - очередная победа робототехники. [online] Доступно: <https://1-tech-fact.livejournal.com/3516.html]> [Дата звернення 20 лютого 2019].

Musion Holograms, 2007. Gorillaz Hologram MTV Awards - Created by Musion Eyeliner, [online] 27 июнь. Доступно: <https://www.youtube.com/watch?v=CRViE4N-u5Y> [Дата звернення 13 березня 2019].

Roffhote, H., Remael, A. and Van den Dris L., 2018. Audio description for (postdramatic) theatre. Preparing the stage. JoSTrans: The journal of specialised translation, 30, p.232-248.

StarLight Entertainment, 2018. VR-тур Вартових Мрій стартує вже 17 листопада. [online] Доступно: <http://e.slm.ua/vr-kyivstar-news1 > [Дата звернення 13 березня 2019].

U!Zahvati. Мы - команда U!ZAHVATI. [online] Доступно: <https://uzahvati.com.ua/> [Дата звернення 20 лютого 2019].

YouTube, 2016. Хацунэ Мику - История успеха. [online] Доступно: <https://www.youtube. com/watch?v=x9leXpRyBOw> [Дата звернення 20 лютого 2019].

\section{REFERENCES}

Antonenko, A., 2018. 16 zhovtnia u Kyievi vidbudetsia premiera "AnderSon" u ramkakh proektu "Art-diia-inkliuziia" [On October 16 in Kyiv, the premiere of "Anderson" will be held within the framework of the project "Art-action-inclusiveness"]. Day Kiev.ua, [online] 12 October. Available at: <https://m.day.kyiv.ua/uk/article/kultura/sluhayemo-vystavy> [Accessed 13 March 2019].

Astafeva, T.V., 2011. Novye tekhnologii v sovremennom postanovochnom protcesse (na materiale teatralnogo iskusstva Sankt-Peterburga) [New technologies in the modern staging process (on the material of the theatrical art of St. Petersburg)]. PhD. Saint-Petersburg Humanitarian University of Trade Unions.

Bazanov, V.V., 2005. Tekhnologiia stceny [Scene technology]. Moscow: Impuls-svet. 
Berezkin, V.I., 2011. Ot istokov do serediny XX veka [From the beginnings to the middle of the $\mathrm{XX}$ century]. In: Iskusstvo stcenografii mirovogo teatra [Art of scenography of the world theater]. Moscow: URSS. Vol. 1

Berezkin, V.I., 2016. Vtoraia polovina XX veka. V zerkale Prazhskikh Kvadriennale 1967-1999 godov [The second half of the twentieth century. In the mirror of the Prague Quadrennial of 1967-1999]. In: Iskusstvo stcenografii mirovogo teatra [Art of scenography of the world theater]. Moscow: Editorial URSS. Vol. 2.

Berezkin, V.I., 2016. Mastera XVI-XX vv [Masters of the XVI-XX centuries]. In: Iskusstvo stcenografii mirovogo teatra [Art of scenography of the world theater]. Moscow: Editorial URSS. Vol. 3.

Goriunova, I.E., 2009. Rezhissura massovykh teatralizovannykh zrelishch i muzykalnykh predstavlenii [Direction of mass theatrical shows and musical notions]. Sankt-Peterburg: Kompozitor, pp.38-43.

Demchuk, A.B., 2014. Videokontent dlia nezriachykh: metod tyflokomentuvannia [Videocontent for the blind: a method of typho-commenting]. Radioelektronika, informatyka, upravlinnia, [online] 1, pp.146-149. Available at: <http://nbuv.gov.ua/UJRN/riu_2014_1_23> [Accessed 20 February 2019].

Drugoi gorod, 2016. Ognenno-pirotekhnicheskii balet-spektakl "Romeo i Dzhuletta" [Fire and pyrotechnic ballet performance "Romeo and Juliet"]. [online] Available at: <http://www. anothercity.ru/fire-show-new> [Accessed 20 February 2019].

Zintcov, 0., 2017. Startoval teatralnyi proekt Cargo Moscow gruppy Rimini Protokoll [The theater project Cargo Moscow of the group Rimini Protokoll started]. Vedomosti, [online] 14 July Available at: <https://www.vedomosti.ru/lifestyle/articles/2017/07/14/723610-cargomoscow> [Accessed 13 March 2019].

Zintcov, O., 2015. Startoval teatralnyi proekt Remote Moscow [Started the theater project "Remote Moscow"]. Vedomosti, [online] 31 May. Available at: <https://www.vedomosti.ru/ lifestyle/articles/2015/06/01/594485-startoval-teatralnii-proekt-remote-moscow $>$ [Accessed 13 March 2019].

Iskusstvo, nauka i sport, 2018. Spektakl s tiflokommentirovaniem na tatarskom iazyke vpervye $v$ Kazani [Performance with Tiflocommentation in the Tatar language for the first time in Kazan]. [online] Available at: <http://artscienceandsport.com/news/specialview_kazan_tiflo> [Accessed 25 February 2019].

Kyivskyi natsionalnyi akademichnyi teatr operety, 2018. Proekt "Art-diiainkliuziia" v Natsionalnii opereti Ukrainy [Project "Art-action-inclusiveness" at the National Operetta of Ukraine]. [online] Available at: <http://operetta.com.ua/ proekt-art-diya-inklyuziya-v-natsionalnij-opereti-ukrayini/> [Accessed 13 March 2019].

Krypchuk, M.V., 2018. Stsenichnyi prostir prosto neba yak skladova suchasnoho teatralizovanoho vydovyshcha [Scenic space of the sky as part of a modern theatrical spectacle]. Visnyk Natsionalnoi akademii kerivnykh kadriv kultury i mystetstv, [online] 2, pp.229-233. Available at: <http://nbuv.gov.ua/UJRN/vdakkkm_2018_2_50> [Accessed 11 December 2018].

Levandovskii, A., 2018. Khabr. Shou dronov: kak my koordinirovali roi tantcuiushchikh kopterov [Habr. Dron Show: How we coordinated a swarm of dancing copters]. [online] Available at: <https://habr.com/ru/company/croc/blog/427353/> [Accessed 20 February 2019].

Lypkivska, H.K., 2018. Multymediini zasoby na suchasnii teatralnii stseni [Multimedia on the modern theater stage]. Visnyk Kyivskoho natsionalnoho universytetu kultury i mystetstv. Seriia: Stsenichne mystetstvo, 1, pp.103-126.

Lisovskii, V., 2016. Neiavnye vozdeistviia Teatr. DOC [Implicit Impact Theater. DOC]. [online] Available at: <http://teatrdoc.ru/events.php?id=172> [Accessed 20 February 2019].

Mystetskyi Arsenal, 2018. Belhiiskyi innovatsiinyi VR-teatr CREW [Belgian innovative VRTheater CREW]. [online] Available at: <https://artarsenal.in.ua/uk/laboratory/proekt/belgijskyjinnovatsijnyj-vr-teatr-crew/> [Accessed 20 February 2019]. 
Mikhailov, L.N., 2007. Sozdanie sovremennogo estradnogo zrelishcha (printcipy khudozhestvennogo oformleniia) [Creation of a modern pop show (principles of decorating)]. D.Ed. Russian Academy of Theater Art. Moscow.

Natsionalna spilka teatralnykh diiachiv Ukrainy, 2017. Robymo teatr dostupnym dlia vsikh! [We make the theater accessible to all!]. [online] Available at: <https://nstdu.com.ua/publication/ ceminar-z-audiodiskriptsiyi-dopomoga-lyudyam-z-vadami-zoru-pobachiti-vistavu/> [Accessed 13 March 2019].

Trykolenko, S.T., 2013. Vykorystannia multymediinykh tekhnolohii dlia oformlennia suchasnykh khoreohrafichnykh postanovok na prykladi shou-baletu "Baron Miunkhhauzen" [Use of multimedia technologies for the execution of modern choreographic productions on the example of the show-ballet "Baron Munchausen"]. "Problems of development of modern choreographic art and ways of their solution": materials of the 3rd All-Ukrainian scientific-practical conference. Lugansk, 5-6 December, 2013. Lugansk: Lugansk State Academy of Culture and Arts, pp.10-109.

Chernyshevskii, N.G., 1981. Zametki o zhurnalakh. liun, iiul 1856. (O razbore N.F. Pavlovym komedii V.A. Solloguba "Chinovnik"). Literaturnaia kritika [otes on magazines. June, July 1856. (On the analysis of NF Pavlov's comedy VA Sollogub "Official"). Literary criticism]. Moscow: Khudozhestvennaia literatura. [online] Vol. 1. Available at: <http://az.lib.ru/c/ chernyshewskij_n_g/text_0400.shtml> [Accessed 20 February 2019].

Ekskuzovich, I.V., 2004. Ob akustike v teatre Maksa Reinkhardta [About acoustics at the Max Reinhardt Theater]. Stcena, 5, p.35.

ludova-Romanova, K.V, 2016. Olfaktorna synesteziia v stsenichnomu mystetstvi [Olfactory synesthesia in stage art.]. Naukovyi visnyk Kyivskoho natsionalnoho universytetu teatru, kino $i$ telebachennia imeni I. K. Karpenka-Karoho,19, pp.29-36.

ludova-Romanova, K.V., 2017. Pnevmatychni zasoby konstruiuvannia stsenichnoho prostoru [Pneumatic tools for designing the stage space]. Visnyk Natsionalnoi akademii kerivnykh kadriv kultury i mystetstv, 4, pp.242-247.

ludova-Romanova, K.V., 2017. Tekhnichni zasoby oformlennia stsenichnoho prostoru [Technical means of recording stage space]. Kyiv: Publishing Center KNUKiM.

ludova-Romanova, K.V., 2018. Dyzain stsenichnoho prostoru vohnianymy zasobamy konstruiuvannia [Design of scenic space by fiery means of design]. Visnyk Natsionalnoi akademii kerivnykh kadriv kultury i mystetstv, 1, pp.228-232.

ludova-Romanova, K.V., 2018. Drony yak skladova innovatsiinoho stsenichnoho dyzainu [Draw as a component of innovative stage design]. The Economy and Culture of Ukraine in Global Globalization Processes: Positioning and Reality: Theses of the Reports of the Third International Scientific and Practical Conference. Kyiv, 21-22 March, 2018. Kyiv: Publishing Center KNUKiM. pp.240-243.

AUSTRO-RUS, 2016. Muzykalnyi festival v Bregentce. [online] Available at: <https://austrorus.ru/articles/166407> [Accessed 13 March 2019].

Brantley, B., 2011. Shakespeare Slept Here, Albeit Fitfully. The New York Times, [online] 13 April 2011. Available at: <https://www.nytimes.com/2011/04/14/theater/reviews/sleep-nomore-is-a-macbeth-in-a-hotel-eview.html?adxnnl=1\&ref=theater\&adxnnlx=1309466383d3DY6sXMRulipZI8XWee5Q> [Accessed 13 March 2019].

Bregenzer Fest Spiele, 2019. [online] Available at: <https://bregenzerfestspiele.com/en\#> [Accessed 13 March 2019].

EVRONEWS, 2017. Na festivale v Bregentce pokazhut "Karmen" [At the festival in Bregenz will show "Carmen"]. [online] Available at: <https://ru.euronews.com/2017/07/19/bregezfestival-carmen> [Accessed 13 March 2019].

Gallo, Ph., 2014. Michael Jackson Hologram Rocks Billboard Music Awards: Watch \& Go Behind the Scenes. Billbord. [online] Available at: <https://www.billboard.com/articles/events/bbma2014/6092040/michael-jackson-hologram-billboard-music-awards> [Accessed 13 March 2019]. 
Globustheatre, 2018. Spektakl "Diadiushkin son" (versiia s tiflokommentariem i subtitrami) / teatr "Globus" [The performance "Uncle Sleep" (version with tiflo-commentary and subtitles) / theater "Globe"]. [online] Available at: <https://youtu.be/msbOIBnNKQ4> [Accessed 20 February 2019].

LiveJournal, 2010. Vystuplenie devushki-robota na stcene - ocherednaia pobeda robototekhniki [The performance of a girl-robot on stage is another victory of robotics]. [online] Available at: <https://1-tech-fact.livejournal.com/3516.html]> [Accessed 20 February 2019].

Musion Holograms, 2007. Gorillaz Hologram MTV Awards - Created by Musion Eyeliner, [online] 27 June Available at: <https://www.youtube.com/watch?v=CRViE4N-u5Y> [Accessed 13 March 2019].

Roffhote, H., Remael, A. and Van den Dris L., 2018. Audio description for (postdramatic) theatre. Preparing the stage. JoSTrans: The journal of specialised translation, 30, p.232-248.

StarLight Entertainment, 2018. VR-tur Vartovykh Mrii startuie vzhe 17 lystopada [The VRtour of Ward's Dream will start on November 17th]. [online] Available at: <http://e.slm.ua/vrkyivstar-news1> [Accessed 13 March 2019].

U!Zahvati. My - komanda U!ZAHVATI [We are a team of U! ZAHVATI]. [online] Available at: <https://uzahvati.com.ua/> [Accessed 20 February 2019].

YouTube, 2016. Khatcune Miku - Istoriia uspekha [Hatsune Miku - The story of success]. [online] Available at: <https://www.youtube.com/watch?v=x9leXpRyBOw> [Accessed 20 February 2019].

\section{РЕЖИССЕРСКИЕ ИННОВАЦИИ В ИСПОЛЬЗОВАНИИ ТЕХНИЧЕСКИХ СРЕДСТВ И ТЕХНОЛОГИЙ В СЦЕНИЧЕСКОМ ИСКУССТВЕ}

\section{Екатерина Юдова-Романова ${ }^{1 a}$, Виктория Стрельчук ${ }^{2 a}$, Юлия Чубукова ${ }^{3 b}$}

\footnotetext{
${ }^{1}$ кандидат искусствоведения, доцент; e-mail: iudovakateryna@gmail.com; ORCID: 0000-0003-2665-390X

${ }^{2}$ кандидат педагогических наук, професcop; e-mail: maximile@ukr.net; ORCID: 0000-0002-8516-5829

${ }^{3}$ магистр; e-mail: julia.pazieieva@gmail.com; ORCID: 0000-0002-9217-9372

а Киевский национальный университет культуры и искусств, Киев, Украина

b 000 «CU Ajans», образовательно-развлекательная и шоу-мейкерская компания, Анталья, Турция
}

\section{Аннотация}

Цель исследования заключается в выявлении и анализе режиссерских инноваций использования технических средств и технологий в сценических постановках как новых, так и традиционных форм. Для достижения поставленной цели использованы следующие методы: теоретический подход - для изучения научной литературы; аналитический и компаративный - определения влияния технологической составляющей на режиссуру современных произведений сценического искусства; системный - проведения структуризации новых жанров сценического искусства, появление которых обусловлено внедрением современных технических средств, инженерных и информационных технологий; прогностический - определения новых тенденций в режиссуре произведений сценического искусства. Научная новизна заключается в искусствоведческом анализе модернизации сценического пространства и изучении роли инновационных технических средств и технологий в режиссуре современных произведений сценического искусства. Выводы. В XXI в. эволюция театрализованных зрелищ происходит под влиянием активного развития технологий и поиска новых способов интерактивности. Характерной чертой современных режиссерских решений является синтез литературной, музыкальной, хореографической, сценографической составляющих, которые воплощаются на различных сценических площадках, модернизация которых заметна как относительно используемых 
материалов, функциональности, мобильности, так и с точки зрения внедрения новейших информационных компьютерных и инженерных технологий. Мультимедийный подход стал одним из ведущих художественно-технологических методов создания современного театрализованного зрелища. Распространение иммерсионных театров и внедрение методов тифлокомментирования (аудиодескрипции) доказывают, что режиссеры современности используют технологии абсолютно разных сторон, а творческие поиски формы позволяют современным языком воплощать сверхзадачу. Мобильность, визуальность, яркость, новаторство, направленность к каждому из зрителей при активном участии последних в действе - основные направления творческих поисков режиссеров.

Ключевые слова: сценическое искусство; технологические средства; режиссерские инновации; мультимедийные технологии; интерактивность

\title{
DIRECTORIAL INNOVATIONS IN THE USE OF TECHNICAL MEANS AND TECHNOLOGIES IN SCENIC ARTS
}

\author{
Kateryna ludova-Romanova ${ }^{1 a}$, Viktoriia Strelchuk ${ }^{2 a}$, Yuliia Chubukova ${ }^{3 b}$ \\ ${ }^{1}$ PhD in Art Studies, Associate Professor; e-mail: iudovakateryna@gmail.com; ORCID: 0000-0003-2665-390X \\ ${ }^{2}$ PhD in Pedagogical Sciences, Professor; e-mail: maximile@ukr.net; ORCID: 0000-0002-8516-5829 \\ ${ }^{3}$ Master; e-mail: julia.pazieieva@gmail.com; ORCID: 0000-0002-9217-9372 \\ ${ }^{a}$ Kyiv National University of Culture and Arts, Kyiv, Ukraine \\ ' LSC "CU Ajans", Educational-entertaining and Show-making Company, Antalya, Turkey
}

\section{Abstract}

The purpose of the study is to identify and analyze directorial innovations in the use of technical means and technologies in the staging of both new and traditional forms. The following methods have been used to achieve this goal: theoretical approach is for the scientific literature study; analytical and comparative are to determine the influence of the technological component on the directing of contemporary works of stage art; systematic is for the structuring of new genres of stage art, the emergence of which is due to the introduction of modern technical means, engineering and information technology; prognostic is to identify new trends in the directing of stage art works. The scientific novelty consists in an art-study analysis of the modernization of the stage space and the study of the innovative technical means role and technologies in the directing of stage art contemporary works. Conclusions. In the XXI century the evolution of theatrical mass sights is under the influence of the technology active development and the search for new ways of interactivity. A feature proper to modern directorial decisions is the synthesis of literary, musical, choreographic, and scenographic components, which are embodied in various stage venues, modernization of which is noticeable both in terms of materials used, functionality, mobility, and in relation to the introduction of the latest information computer and engineering technologies. The multimedia approach has become one of the leading creative and technological methods of creating a contemporary theatrical spectacle. The proliferation of immersion theaters and the introduction of audio descriptions methods have proved that contemporary directors use technology in a very versatile way, and creative forms of search enable the modern language to translate the super-task. Mobility, visibility, brightness, innovation, orientation to each of the spectators with the active participation of the latter in the action are the main areas of creative search for directors.

Keywords: stage art; technological means; directorial innovations; multimedia technologies; interactivity 